\title{
PENERAPAN STUDI REKAYASA NILAI PADA PERENCANAAN \\ STRUKTUR ATAP GEDUNG SERBA GUNA UNIVERSITAS MUHAMMADIYAH MALANG
}

\author{
Dyah Retno ${ }^{1}$, Hermy Dyah Hastuti ${ }^{2}$
}

\begin{abstract}
This research will apply value engineering study in planing roof Astructure of UMM's Multi Function Building (GSG). The planing includes roof geometry and material used as roof cover and skeletons. Steps taken includes information stage that have goal in determining criteria necessary in planing the roof structure and weight of the criteria, creativity stage in which we will develop roof structure alternatives as many as possible by using FAST diagram, and then evaluation stage in which we will make assessment on those alternatives by using feasibility and evaluation matrix, performance calculation, and calculation of cost required by respective alternatives. In development stage we will make value calculation of respective alternatives, in which an alternative with the highest value will be chosen as proposal for roof of UMM's Multi Function Building.
\end{abstract}

Key Words : Engineering, FAST, Matrix

\section{PENDAHULUAN}

Proyek Gedung SerbaGuna UMM yang berlokasi di area Kampus III UMM adalah salah satu proyek yang ditangani langsung oleh Universitas Muhammadiyah Malang mulai dari perencanaan, pelaksanaan, serta pengawasan suatu proyek khususnya yang berhubungan dengan arsitektur dan strukur bangunan. Faktor yang perlu dipertimbangkan pada bangunan seperti ini adalah kelengkapan utilitas seperti AC, alarm, listrik, lift, dan lain sebagainya.

Gedung Serba Guna dapat dipergunakan untuk pertemuan berskala besar seperti acara wisuda. Oeh sebab itu keberadaan kolom di tengah menjadikan ruangan kurang fleksibel. Karena itu ruang seperti ini disarankan tidak ada penghalang, sehubungan dengan hal ini maka dicari alternatif lain dari strukur atap yang dapat memenuhi kriteria diatas dengan bobot yang tidak besar karena bobot yang ringan dapat memperkecil dimensi kolom dan secara tidak langsung dan secara tidak langsung dapat menekan biaya konstruksi secara keseluruhan.

Untuk mendapatkan struktur atap yang optimal, maka perlu dicari beberapa alternatif struktur atap yang dapat diterapkan pada Gedung Serba Guna UMM ini sehingga akan didapatkan alternatif strukur atap yang terbaik. Dalam penelitian ini akan digunakan studi rekayasa nilai untuk merencanakan struktur atap tersebut. 


\section{TINJAUAN PUSTAKA}

Laurens D. Miles, 1972. menjelaskan "rekayasa nilai adalah suatu pendekatan yang bersifat kreatif dan sistematis dengan tujuan untuk mengurangi atau menghilangkan biaya-biaya yang tidak diperlukan". Sedangkan Edward D. Heller,1971. mengemukakan "rekayasa nilai merupakan suatu penerapan sistematis dari sejumlah teknik untuk mengidentifikasikan fungsi-fungsi suatu benda/jasa dengan memberi nilai terhadap masing-masing fungsi yang ada serta mengembangkan sejumlah alternatif yang memungkinkan tercapainya fungsi tersebut dengan biaya total minimum".

Dari definisi diatas terlihat bahwa teknik rekayasa nilai menggunakan suatu pendekatan sistematis untuk mendefinisikan fungsi-fungsi yang diinginkan dalam mendesain suatu sistem, produk dan jasa, mengukur performansi fungsi-fungsinya, sehingga performansi akhir yang akan dihasilkan akan sama atau mendekati performansi yang diinginkan pemakai dengan pertimbangan biaya yang optimal.

Rekayasa nilai mempunyai tujuan untuk mendapatkan nilai yang semaksimal mungkin. Sedangkan nilai atau value dapat dirumuskan sebagai perbandingan antara performansi yang ditampilkan suatu fungsi terhadap biaya yang dikeluarkan untuk mendapatkan fungsi tersebut.

Value $=$ performansi $/$ biaya performansi $=$ keuntungan atau manfaat yang diperoleh dari fungsi-fungsi suatu produk atau jasa.

biaya $=$ biaya total yang dikeluarkan untuk mendapatkan fungsi yang diinginkan.

\section{Tahapan dalam rekayasa nilai}

Ada lima tahapan yaitu :

\section{Tahap Informasi}

Pada tahap ini dikumpulkan semua informasi yang berhubungan dengan proyek yang akan direncanakan.

2. Tahap Kreatifitas

Tujuan dari tahap ini adalah untuk menghasilkan berbagai alternatif untuk memenuhi fungsi utama yang dilaksanakan dengan menggunakan teknik kreatifitas.

3. Tahap Analisa

Tujuan dari tahap ini adalah menganalisa alternatif-alternatif yang dihasilkan dari tahap kreatifitas. Pada tahap ini akan diteliti kelebihan dan kekurangan ide-ide untuk menghasilkan alternatif. Selama tahapan ini, jumlah ide yang dikembangkan dan diteliti akan berkurang.

4. Tahap Pengembangan

Tujuan dari tahap ini adalah untuk mempersiapkan rekomendasi akhir yang tertulis bagi alternatif akhir yang terpilih untuk diimplementasikan termasuk pertimbangan-pertimbangan faktorfaktor teknis dan ekonomis yang secara lengkap dikembangkan untuk memungkinkan untuk diimplementasikan.

dimana : 


\section{Tahap Presentasi}

Tujuan dari tahap ini adalah untuk menyajikan hasil yang telah dikembangkan secara lengkap dan direkomendasikan pada tahap pengembangan.

\section{Teknik-teknik dalam tahapan rekayasa} nilai

Beberapa teknik analisa yang dipergunakan dalam tahapan rencana kerja rekayasa nilai adalah :

Tabel 1

Teknik-Teknik Dalam Rekayasa Nilai

\begin{tabular}{|c|c|}
\hline Tahap & Teknik yang dipergunakan \\
\hline Informasi & $\begin{array}{ll}\text { - } & \text { Kuisioner } \\
\text { - } & \text { Peramalan } \\
\text { - } & \text { Analisa Pasar }\end{array}$ \\
\hline Kreatifitas & $\begin{array}{ll}\text { - } & \text { Analisa Morfologi } \\
\text { - } & \text { Analisa Black Box } \\
\text { - } & \text { Analisa Fungsi (FAST) } \\
\text { - } & \text { Matrik Input Output }\end{array}$ \\
\hline Evaluasi & $\begin{array}{ll}\text { - } & \text { Analisis Hierarki Proses } \\
\text { - } & \text { Matrik Evaluasi } \\
\text { - } & \text { Matrik Kelayakan } \\
\text { - } & \text { Analisis Performansi } \\
\text { - } & \text { Analisis Biaya }\end{array}$ \\
\hline
\end{tabular}

\section{Analisa Fungsi}

Fungsi dapat didefinisikan sebagai tujuan dasar yang diinginkan dari suatu sistem. Fungsi juga merupakan karakteristik dari suatu produk/desain yang dapat membuatnya bekerja/laku dijual. Secara umum fungsi dapat dibadakan atas fungsi dasar dan fungsi pendukung.
Salah satu teknik analisa fungsi yang banyak digunakan adalah Function Analys System Technique (FAST). FAST merupakan suatu teknik penyusunan secara sistematik fungsi-fungsi yang diperlukan. Teknik ini bertujuan " untuk menyederhanakan desain, operasi, rencana, atau prosedur kedalam elemen-elemen fungsional yang teridentifikasi.

\section{Analisa Hirarki Proses (AHP)}

AHP menyususn suatu masalah menjadi satu hierarki yang terstruktur dan dapat dengan mudah dipahami dan dianalisis. Proses berpikir analitis yang terdapat dalam AHP didasarkan pada prinsip-prinsip yang ditinjau dari aspek kualitatif dan kuantitatif yaitu :

- Secara kualitatif AHP mendefinisikan permasalahan dan menyusun permasalahan kedalam suatu hierarki.

- Secara kuantitatif AHP melakukan perbandingan dan penilaian untuk mendapatkan solusi permasalahan

\section{METODOLOGI PENELITIAN}

1. Tahap Informasi

Tahap ini bertujuan untuk mengumpulkan informasi yang berhubungan dengan proyek yang direncanakan. Untuk mengetahui kriteria-kriteria desain produk yang diperlukan maka dilakukan penyebaran kuisioner kepada responden sebanyak 40 orang (12 angket diberikan pada para ahli/proyek dan 28 angket diberikan pada mahasiswa teknik sipil) 


\section{Tahap Kreatif}

Tahap ini bertujuan untuk mengembangkan sebanyak mungkin alternatif yang memenuhi fungsi yang diperlukan. Untuk itu dilakukan analisa fungsi dengan menggunakan FAST.

3. Tahap Analisa/Evaluasi

- Menyebarkan kuisioner yang selanjutnya diolah meliputi perhitungan bobot kriteria, pengujian konsistensi data, dan perhitungan bobot fungsi.

- Analisa keuntungan dan kerugian Analisa ini digunakan sebagai salah satu cara untuk mencari alternatif yang direkomendasikan dengan melihat keuntungan dan kerugian dari alternatif tersebut.

- Matrik kelayakan

Matrik ini merupakan salah satu langkah yang diambil dalam mempertimbangkan alternatif yang akan dipilih. Pertimbangan yang dilakukan didasarkan pada kriteriakriteria yang telah ditentukan pada tahap informasi.

- Matrik evaluasi

Matrik ini digunakan untuk mengambil keputusan dari beberapa alternatif dengan jalan mengkombinasikan kriteria kualitatif dan kriteria kuantitatif.

- Analisa performansi

Pada tahap ini akan dilakukan penilaian performansi dari alternatif-alternatif yang terpilih pada matrik evaluasi. Performansi dari masing-masing alternatif diperoleh dengan cara mengalikan total bobot kriteria dengan nilai kriteria dari matrik evaluasi.

- Analisa biaya

Pada tahap ini akan dilakukan perhitungan biaya-biaya yang akan dikeluarkan bila alternatif tersebut terpilih.

\section{Tahap pengembangan}

Pada tahap ini akan dilakukan perbandingan antara desain awal dengan desain usulan ditinjau dari faktor teknis dan ekonomis dengan jalan analisa keuntungan dan kerugian.

5. Tahap rekomendasi

Pada tahap ini akan dilakukan perhitungan value dari alternatif yang direkomendasikan, selanjutnya alternatif dengan value tertinggi akan dipilih.

\section{HASIL DAN PEMBAHASAN}

Dari hasil penyebaran kuisioner didapatkan kriteria gedung serba guna yang ideal yaitu :

1. Daya dukung : kekuatan konstruksi dalam mendukung beban

2. Jenis Material : material yang digunakan dalm kontruksi atap gedung serba guna

3. Waktu kontruksi : berapa lama sebuah konstruksi atap dapat diselesaikan.

4. Arsitektural : keserasian dari konstruksi atap GSG sesuai dengan keinginan konsumen. 
5. Estetika : keindahan dari konstruksi atap GSG sehingga memiliki nilai seni yang tinggi.

6. Desain : bentuk dari konstruksi atap GSG.

7. Penghematan : kriteria tentang besar/kecilnya biaya yang dikeluarkan dalam perencanaan struktur atap GSG.

8. Pemeliharaan : mudah/tidaknya cara perawatan dari konstruksi atap GSG.

9. Daya tahan : umur/keawetan dari konstruksi atap.

Selanjutnya dari pengolahan hasil kuesioner terhadap bobot kontribusi dari masing-masing kriteria diperoleh :

\section{Tabel 2}

\section{Kontribusi Kriteria}

\begin{tabular}{|c|l|c|}
\hline No & \multicolumn{1}{|c|}{ Kriteria } & Bobot (\%) \\
\hline 1 & Daya dukung & 11,46 \\
2 & Jenis Material & 12,51 \\
3 & Waktu Konstruksi & 8,91 \\
4 & Arsitektural & 11,28 \\
5 & Estetika & 11,56 \\
\hline 6 & Desain & 11,18 \\
7 & Penghematan & 11,64 \\
8 & Pemeliharaan & 10,41 \\
9 & Daya tahan & 11,04 \\
\hline
\end{tabular}

Sedangkan fungsi operasional dari struktur atap GSG adalah :

- Fungsi 11 Perlindungan terhadap hujan

- Fungsi 12 Perlindungan terhadap sinar matahari

- Fungsi 13 Perlindungan terhadap angin

- Fungsi 21 Beban dinamis

- Fungsi 22 beban statis

- Fungsi 31 Segi bentuk

- Fungsi 32 Pendukung atap

Selanjutnya berdasarkan fungsifungsi dasar tersebut dibuat sebuah diagram
FAST. Dari diagram FAST selanjutnya akan terbentuk alternatif-alternatif desain struktur atap. Dimana masing-masing alternatif akan tersususn dari beberapa faktor yaitu :

- Memberikan perlindungan

- Memberikan keamanan /' Statistika pembebanan

- Memberikan nilai estetika.

Alternatif desain atap yang dimunculkan dapat dilihat pada tabel 3 berikut ini :

Tabel 3

Alternatif Desain Atap yang Dimunculkan

\begin{tabular}{|l|l|l|l|l|}
\hline No & Alternatif & $\begin{array}{c}\text { Bentuk } \\
\text { Atap }\end{array}$ & $\begin{array}{c}\text { Penutup } \\
\text { Atap }\end{array}$ & $\begin{array}{c}\text { kuda } \\
\text { kuda }\end{array}$ \\
\hline 1 & $\begin{array}{l}\text { Desain } \\
\text { awal }\end{array}$ & Kubah & Space Frame & - \\
\hline 2 & Alternatif 1 & Datar & $\begin{array}{l}\text { Beton } \\
\text { Bertulang }\end{array}$ & - \\
\hline 3 & Alternatif 2 & Kubah & $\begin{array}{l}\text { Beton } \\
\text { Bertulang }\end{array}$ & - \\
\hline 4 & Alternatif 3 & Pelana & $\begin{array}{l}\text { Genteng } \\
\text { Beton }\end{array}$ & Baja \\
\hline 5 & Alternatif 4 & Pelana & $\begin{array}{l}\text { Seng } \\
\text { Gelombang }\end{array}$ & Baja \\
\hline 6 & Alternatif 5 & Perisai & $\begin{array}{l}\text { Genteng } \\
\text { Beton }\end{array}$ & Baja \\
\hline 7 & Alternatif 6 & Perisai & $\begin{array}{l}\text { Seng } \\
\text { Gelombang }\end{array}$ & Baja \\
\hline 8 & Alternatif 7 & Datar & Sirap kayu & - \\
\hline 9 & Alternatif 8 & Datar & Asbes & - \\
\hline 10 & Alternatif 9 & Datar & $\begin{array}{l}\text { Seng } \\
\text { Gelombang }\end{array}$ & - \\
\hline 11 & $\begin{array}{l}\text { Alternatif } \\
10\end{array}$ & Datar & Bambu & - \\
\hline 12 & $\begin{array}{l}\text { Alternatif } \\
11\end{array}$ & Datar & $\begin{array}{l}\text { Tumbuh- } \\
\text { tumbuhan }\end{array}$ & - \\
\hline 13 & $\begin{array}{l}\text { Alternatif } \\
12\end{array}$ & Pelana & Sirap kayu & Kayu \\
\hline 14 & $\begin{array}{l}\text { Alternatif } \\
13\end{array}$ & Pelana & Asbes & Baja \\
\hline 15 & $\begin{array}{l}\text { Alternatif } \\
14\end{array}$ & Pelana & Bambu & Kayu \\
\hline 16 & $\begin{array}{l}\text { Alternatif } \\
15\end{array}$ & Pelana & $\begin{array}{l}\text { Tumbuh- } \\
\text { tumbuhan }\end{array}$ & Kayu \\
\hline 17 & $\begin{array}{l}\text { Alternatif } \\
16\end{array}$ & Perisai & Sirap kayu & Kayu \\
\hline 18 & $\begin{array}{l}\text { Alternatif } \\
17\end{array}$ & Perisai & Asbes & Baja \\
\hline 19 & $\begin{array}{l}\text { Alternatif } \\
18\end{array}$ & Perisai & Bambu & Kayu \\
\hline 20 & $\begin{array}{l}\text { Alternatif } \\
19\end{array}$ & Perisai & $\begin{array}{l}\text { Tumbuh- } \\
\text { tumbuhan }\end{array}$ & Kayu \\
\hline
\end{tabular}


Dari ke-19 alternatif yang dikembangkan selanjutnya beberapa alternatif yang tidak mungkin dilakukan dihilangkan.

Tabel 4

Alternatif Desain yang Dimunculkan

\begin{tabular}{|c|c|c|c|c|}
\hline No & Alternatif & $\begin{array}{c}\text { Bentuk } \\
\text { Atap }\end{array}$ & $\begin{array}{c}\text { Penutup } \\
\text { Atap }\end{array}$ & $\begin{array}{c}\text { Kuda- } \\
\text { kuda }\end{array}$ \\
\hline 1 & Alternatif 1 & Datar & $\begin{array}{l}\text { Beton } \\
\text { Bertulang }\end{array}$ & - \\
\hline 2 & Alternatif 2 & Kubah & $\begin{array}{l}\text { Beton } \\
\text { Bertulang }\end{array}$ & - \\
\hline 3 & Alternatif 3 & Pelana & $\begin{array}{l}\text { Genteng } \\
\text { Beton }\end{array}$ & Baja \\
\hline 4 & Alternatif 4 & Pelana & $\begin{array}{l}\text { Seng } \\
\text { Gelombang }\end{array}$ & Baja \\
\hline 5 & Alternatif 5 & Perisai & $\begin{array}{l}\text { Genteng } \\
\text { Beton }\end{array}$ & Baja \\
\hline 6 & Alternatif 6 & Perisai & $\begin{array}{l}\text { Seng } \\
\text { Gelombang }\end{array}$ & Baja \\
\hline 7 & Alternatif 13 & Pelana & Asbes & Baja \\
\hline 8 & Alternatif 17 & Perisai & Asbes & Baja \\
\hline
\end{tabular}

Dari ke-delapan alternatif desain ditambah dengan desain awal yang diperoleh maka langkah selanjutnya masuk pada tahap evaluasi.

Dengan menyebar kuesioner terhadap 10 responden yang ahli dalam perencanaan struktur maka diperoleh matriks kelayakan dari alternatif-alternatif desain. Kriteria penilaian yang digunakan dalam perencanaan struktur atap tersebut adalah :

- Kriteria A : Teknologi dan Penggunaan

- Kriteria B : Biaya Pengembangan

- Kriteria C : Kemungkinan Pelaksanaan

- Kriteria D : Waktu Pelaksanaan

o Kriteria E : Penghematan

Nilai yang diberikan dari masing-masing kriteria adalah antara 1 sampai

Tabel 5

Ranking Penilaian Matriks Kelayakan

\begin{tabular}{|c|l|c|c|c|c|c|c|c|}
\hline No & \multirow{2}{*}{$\begin{array}{c}\text { Alternatif } \\
\text { desain }\end{array}$} & \multicolumn{5}{|c|}{ Kriteria } & Total & $\begin{array}{c}\text { Rankin } \\
\text { g }\end{array}$ \\
\cline { 3 - 8 } & & A & B & C & D & E & & \\
\hline 1 & Desain Awal & 82 & 74 & 81 & 80 & 70 & 387 & 1 \\
\hline 2 & Alternatif 1 & 80 & 68 & 68 & 78 & 74 & 368 & 3 \\
\hline 3 & Alternatif 2 & 81 & 69 & 78 & 80 & 76 & 384 & 2 \\
\hline 4 & Alternatif 3 & 57 & 51 & 47 & 45 & 46 & 246 & 4 \\
\hline 5 & Alternatif 4 & 53 & 33 & 46 & 42 & 47 & 221 & 6 \\
\hline 6 & Alternatif 5 & 46 & 45 & 47 & 47 & 43 & 229 & 5 \\
\hline 7 & Alternatif 6 & 39 & 50 & 36 & 46 & 41 & 212 & 7 \\
\hline 8 & Alternatif 13 & 41 & 42 & 45 & 49 & 47 & 183 & 9 \\
\hline 9 & Alternatif 17 & 46 & 38 & 39 & 42 & 42 & 207 & 8 \\
\hline
\end{tabular}


Dari matriks tersebut dapat dilihat bahwa desain awal berada pada urutan pertama dengan total 387 sedangkan desain ke-2 menempati urutan kedua dengan nilai 384.

Selanjutnya dengan menyebarkan kuesioner sekali lagi kepada para 10 ahli di bidang perencanaan struktur didapatkan sebuah matriks evaluasi. Kriteria yang digunakan dalam matriks evaluasi ada sebanyak sembilan yaitu

- Kriteria 1 : jenis material (kriteria tentang material yang digunakan dalam konstruksi atap).

- Kriteria 2 : biaya/penghematan (kriteria tentang besar/kecilnya biaya yang dikeluarkan dalam perencanaan struktur atap GSG).

- Kriteria 3 : estetika (kriteria tentang keindahan dari konstruksi atap GSG sehingga memiliki nilai seni yang tinggi).

- Kriteria 4 : daya dukung (kriteria tentang kekuatan konstruksi dalam mendukung beban).
- Kriteria 5 : Arsitektural (Kriteria tentang eserasian dari konstruksi atap GSG sesuai dengan keinginan konsumen).

- Kriteria 6 : desain/bentuk (Kriteria tentang bentuk konstruksi atap GSG).

- Kriteria 7 : Daya tahan/keawetan (Kriteria tentang umur/keawetan dari konstruksi atap GSG).

- Kriteria 8 : Pemeliharaan (Kriteria tentang mudah/tidaknya cara perawatan dari konstruksi atap GSG).

- Kriteria 9 : Waktu konstruksi (Kriteria berapa lama sebuah konstruksi atap GSG dapat diselesaikan).

Dan skala penilaian dimulai dari 1 sampai 10.

Setelah hasil dari kuesioner tersebut diolah didapatkan matriks evaluasi yang dapat dilihat pada tabel

Tabel 6

Ranking Matriks Evaluasi

\begin{tabular}{|c|l|c|c|c|c|c|c|c|c|c|c|c|}
\hline No & \multicolumn{1}{|c|}{ Alternatif } & \multicolumn{9}{|c|}{ Kriteria } & Total & Ranking \\
\hline & \multicolumn{1}{|c|}{ Desain } & 1 & 2 & 3 & 4 & 5 & 6 & 7 & 8 & 9 & & \\
\hline 1 & Desain Awal & 94 & 71 & 95 & 93 & 89 & 94 & 91 & 91 & 77 & 795 & 1 \\
\hline 2 & Alternatif 1 & 75 & 75 & 74 & 71 & 74 & 76 & 70 & 80 & 69 & 664 & 3 \\
\hline 3 & Alternatif 2 & 87 & 88 & 90 & 78 & 88 & 87 & 85 & 91 & 78 & 772 & 2 \\
\hline 4 & Alternatif 3 & 67 & 65 & 75 & 72 & 66 & 81 & 69 & 68 & 70 & 633 & 4 \\
\hline 5 & Alternatif 4 & 67 & 69 & 70 & 65 & 69 & 71 & 61 & 68 & 68 & 608 & 7 \\
\hline 6 & Alternatif 5 & 70 & 66 & 76 & 62 & 65 & 77 & 66 & 64 & 68 & 614 & 6 \\
\hline 7 & Alternatif 6 & 66 & 69 & 79 & 63 & 70 & 79 & 59 & 66 & 67 & 618 & 5 \\
\hline 8 & Alternatif 13 & 62 & 66 & 72 & 61 & 67 & 72 & 64 & 66 & 66 & 596 & 8 \\
\hline 9 & Alternatif 17 & 66 & 62 & 70 & 60 & 67 & 69 & 65 & 69 & 68 & 532 & 9 \\
\hline
\end{tabular}


Tabel 7

Analisa Performansi dari Alternatif desain Struktur Atap

\begin{tabular}{|c|c|c|c|c|c|c|c|c|c|c|c|}
\hline \multirow{4}{*}{$\begin{array}{l}\text { Altern } \\
\text { atif }\end{array}$} & \multicolumn{9}{|c|}{ Kriteria } & \multirow[t]{3}{*}{ Pn } & \multirow{3}{*}{$\begin{array}{l}\text { Ran- } \\
\text { king }\end{array}$} \\
\hline & 1 & 2 & 3 & 4 & 5 & 6 & 7 & 8 & 9 & & \\
\hline & \multicolumn{9}{|c|}{ Bobot Tiap Kriteria } & & \\
\hline & 0,3372 & 0,1988 & 0,1633 & 0,0952 & 0,0666 & 0,0600 & 0,0450 & 0,0314 & 0,0184 & & \\
\hline Awal & 94 & 71 & 95 & 93 & 89 & 94 & 91 & 91 & 77 & 89,63 & 1 \\
\hline 1 & 75 & 75 & 74 & 71 & 74 & 76 & 70 & 80 & 69 & 75,06 & 3 \\
\hline 2 & 87 & 88 & 90 & 78 & 88 & 87 & 85 & 91 & 78 & 87,67 & 2 \\
\hline 3 & 67 & 65 & 75 & 72 & 66 & 81 & 69 & 68 & 70 & 70,04 & 4 \\
\hline 4 & 67 & 69 & 70 & 65 & 69 & 71 & 61 & 68 & 68 & 68,54 & 7 \\
\hline 5 & 70 & 66 & 76 & 62 & 65 & 77 & 66 & 64 & 68 & 69,86 & 6 \\
\hline 6 & 66 & 69 & 79 & 63 & 70 & 79 & 59 & 66 & 67 & 69,85 & 5 \\
\hline 13 & 62 & 66 & 72 & 61 & 67 & 72 & 64 & 66 & 66 & 66,17 & 9 \\
\hline 17 & 66 & 62 & 70 & 60 & 67 & 69 & 65 & 69 & 68 & 66,30 & 8 \\
\hline
\end{tabular}

Berdasarkan dari hasil analisa performansi diatas maka nilai performansi yang tertinggi adalah desain awal, alternatif 2 dan alternatif desaian 1

Selanjutnya dilakukan analisa biaya yang diperlukan untuk pembangunan konstruksi atap tersebut. Sebelum dilakukan perhitungan biaya, terlebih dahulu dilakukan perhitungan volume desain atap pada setiap alternatif. Biaya dihitung berdasarkan biaya untuk pembelian material dan biaya tenaga kerja. Tabel 8 menunjukkan biaya yang dikeluarkan untuk masing-masing alternatif

Tabel 8

Estimasi Biaya Untuk Tiap Alternatif Desain Atap

\begin{tabular}{|c|c|c|c|c|c|}
\hline Alt & Uraian & $\begin{array}{l}\text { Volume } \\
\text { (m3) }\end{array}$ & Harga satuan (Rp) & $\begin{array}{l}\text { Jumlah Harga } \\
\qquad(\mathrm{Rp})\end{array}$ & Total (Rp) \\
\hline Awal & $\begin{array}{l}\text { Pengadaan plat BHP dan } \\
\text { Pemasangan gor-ding, glass wool, } \\
\text { alumunium foil, ply-wood, water } \\
\text { proofing membran dan finishing }\end{array}$ & 4850 & & & 995.231 .120 \\
\hline 1 & $\begin{array}{l}\text { Pekerjaan dan Pe-ngecoran atap } \\
\text { datar beton bertulang }\end{array}$ & 1740,42 & 227.202 & $395.426 .904,8$ & $395.426 .904,8$ \\
\hline 2 & $\begin{array}{l}\text { Pekerjaan dan Pe-ngecoran atap } \\
\text { kubah beton bertulang }\end{array}$ & 2295,92 & 233.852 & $536.905 .483,5$ & $536.905 .483,5$ \\
\hline 3 & $\begin{array}{l}\text { - Pekerjaan rangka atap serta } \\
\text { pekerjaan kuda - kuda dengan } \\
\text { luas } 50 \mathrm{~m} 2 \\
\text { - Memasang genteng kodok Ex. } \\
\text { Bambe }\end{array}$ & 29000 & $\begin{array}{c}27.200 \\
(\operatorname{tiap} \mathrm{m} 2) \\
2.250\end{array}$ & 65.250 .000 & 482.253 .200 \\
\hline
\end{tabular}




\begin{tabular}{|c|c|c|c|c|c|}
\hline Alt & Uraian & $\begin{array}{c}\text { Volume } \\
\text { (m3) }\end{array}$ & $\begin{array}{l}\text { Harga satuan } \\
\text { (Rp) }\end{array}$ & $\begin{array}{c}\text { Jumlah Harga } \\
(\mathbf{R p})\end{array}$ & Total (Rp) \\
\hline 4 & $\begin{array}{l}\text { o Pekerjaan rangka atap serta } \\
\text { pekerjaan kuda-kuda dengan luas } \\
50 \mathrm{~m} 2 \\
\text { o Memasang seng gelombang BJLS } \\
30\end{array}$ & 306,62 & $\begin{array}{c}27.200 \\
(\text { tiap } \mathrm{m} 2)\end{array}$ & 417.003 .200 & 422.703 .200 \\
\hline 5 & $\begin{array}{l}\text { - Pekerjaan rangka atap serta } \\
\text { pekerjaan kuda-kuda dengan luas } \\
50 \mathrm{~m} 2 \\
\text { - Memasang genteng kodok Ex. } \\
\text { Bambe }\end{array}$ & 313,12 & $\begin{array}{c}27.200 \\
(\text { tiap } \mathrm{m} 2)\end{array}$ & 425.843 .200 & 491.093 .200 \\
\hline 6 & $\begin{array}{l}\text { - Pekerjaan rangka atap serta } \\
\text { pekerjaan kuda-kuda dengan luas } \\
50 \mathrm{~m} 2 \\
\text { O Memasang seng gelombang BJLS } \\
30\end{array}$ & 313,12 & $\begin{array}{c}27.200 \\
\text { (tiap m2) } \\
\\
47.500 \\
\end{array}$ & 425.843 .200 & 431.543 .200 \\
\hline 13 & $\begin{array}{l}\text { - Pekerjaan rangka atap serta } \\
\text { pekerjaan kuda-kuda dengan luas } \\
50 \mathrm{~m} 2 \\
\text { - Memasang asbes gelombang } \\
\text { besar tebal } 5 \mathrm{~mm}\end{array}$ & $\begin{array}{l}306,63 \\
160.125 \\
\end{array}$ & $\begin{array}{c}27.200 \\
(\operatorname{tiap} \mathrm{m} 2) \\
22.500 \\
\end{array}$ & $3.602 .812,5$ & 420.606 .200 \\
\hline 17 & $\begin{array}{l}\text { - Pekerjaan rangka atap serta } \\
\text { pekerjaan kuda-kuda dengan luas } \\
50 \mathrm{~m} 2 \\
\text { - Memasang asbes gelombang } \\
\text { besar tebal } 5 \mathrm{~mm}\end{array}$ & 160.125 & $\begin{array}{c}27.200 \\
(\text { tiap } \mathrm{m} 2) \\
22.500 \\
\end{array}$ & $\begin{array}{l}4.425 .843 .200 \\
3.602 .812,5 \\
\end{array}$ & $429.446 .012,5$ \\
\hline
\end{tabular}

Setelah perhitungan performansi dan biaya telah dilakukan maka langkah selanjutnya adalah menghitung value dari masing-masing alternatif desain struktur. Rumus yang digunakan adalah :

$$
V^{\prime}=\frac{\frac{C_{D A}}{P_{D A}} \cdot P^{\prime}}{C^{\prime}}
$$

\section{Dimana :}

$\mathrm{V}^{\prime}=$ value dari desain alternatif.

$\mathrm{P}^{\prime}=$ Performansi pada kondisi desain sebenarnya/alternatif desain.

$\mathrm{C}^{\prime}=$ Biaya pada kondisi desain sebenarnya/alternatif desain.

$\mathrm{C}_{\mathrm{DA}}=$ Biaya pada kondisi desain awal.

$\mathrm{P}_{\mathrm{DA}}=$ Performansi pada kondisi desain awal.
Nilai value dari masing-masing alternatif dapat dilihat pada tabel 9.

Tabel 9

Value dari Alternatif Desain Struktur Atap

\begin{tabular}{|l|l|c|c|}
\hline No & Alternatif & Value & Ranking \\
\hline 1 & Desain Awal & 1 & 9 \\
\hline 2 & Alternatif 1 & 2,1077 & 1 \\
\hline 3 & Alternatif 2 & 1,8131 & 2 \\
\hline 4 & Alternatif 3 & 1,6126 & 7 \\
\hline 5 & Alternatif 4 & 1,8004 & 3 \\
\hline 6 & Alternatif 5 & 1,5796 & 8 \\
\hline 7 & Alternatif 6 & 1,7973 & 4 \\
\hline 8 & Alternatif 13 & 1,7470 & 5 \\
\hline 9 & Altematif 17 & 1,7143 & 6 \\
\hline
\end{tabular}

Dari tabel diatas maka dapat dilihat bahwa alternatif desain yang memiliki value tertinggi adalah desain 1 dengan value 2,1077 diikuti dengan desain 2 dengan value 1,8131.

Sehingga desain 1 yang memiliki spesifikasi teknis bentuk atap datar, penutup atap terbuat dari beton bertulang dengan luas 
atap $50 \mathrm{~m} 2$ dapat dikembangkan sebagai struktur atap untuk GSG UMM dengan biaya yang diperlukan sebesar Rp. 395.426.904,8. Selanjutnya laternatif 2 juga dapat dikembangkan apabila alternatif 1 tidak dapat direalisasikan.

Keuntungan jika alternatif desain 1 digunakan sebagai konstruksi atap GSG UMM adalah :

- bahan yang digunakan tahan api sehingga tidak mudah terbakar. Tidak mudah rusak oleh hujan dan panas.

- Tahan lama/awet.

- Tidak perlu perawatan.

Disamping itu biaya yang diperlukan akan lebih kecil dibandingkan dengan desain awal yang menggunakan konstruksi space frame serta pelaksanaan dengan desain 1 akan lebih mudah dilakukan dibanding dengan konstruksi space frame yang masih sangat langka ditemui di Indonesia.

\section{KESIMPULAN}

Kriteria yang dibutuhkan dalam perencanaan struktur atap GSG UMM adalahJenis material, penghematan, estetika, arsitektural, desain/bentuk, daya tahan, pemeliharaan dan waktu konstrusi.

Dari perhitungan value maka alternatif desain 1 (atap datar dengan beton bertulang) memiliki value tertinggi, diikuti desain 2 (atap kubah dengan beton bertulang). Selanjutnya desain 1 lebih baik digunakan sebagai alternatif konstruksi atap untuk Gedung Serba Guna UMM daripada desain awal yaitu dengan konstruksi space frame.

\section{DAFTAR PUSTAKA}

Bie Weking, G., Rencana Anggaran Borongan Bangunan, Daftar Analisa Upah dan Bahan, Citra Pindo, Bandung.

Edwart D. Heller 1971, Value Management : Value Engineering and Cost Reduction, Addison Wesley Publishing Company,

Giasindo Teknik P.,2001 Teknologi Bahan

Konstruksi Atap Modern, Rangka ruang dengan menggunakan Ball Joint sebagai Titik Simpul, makalah Seminar.

Gunawan, Rudy dan Petunjuk Morisco, Tabel Profil Konstruksi Baja, Kanisius.

Lawrence D. Miles, 1972., Techniauesn of Value Analysis and Engineering, McGraw Hill Book Company, Potma, AP dan Devries J.E., Konstruksi Baja, Teori, Perhitungan dan Pelaksanaan, PT. Pradnya Paraminta, Jakarta.

Sudjana,1975, Statistika Untuk Ekonomi dan Niaga, Tarsito, Bandung.

Sunggono Kh., Buku Teknik Sipil, Penerbit NOVA. 